\title{
Influence of Acid Modification Multiwall Carbon Nanotube Counter Electrodes on the Glass and Flexible Dye-Sensitized Solar Cell Performance
}

\author{
Wasan Maiaugree, ${ }^{1}$ Samuk Pimanpang, ${ }^{1,2,3}$ \\ Wirat Jarernboon, ${ }^{1,2}$ and Vittaya Amornkitbamrung ${ }^{1,2,3}$ \\ ${ }^{1}$ Department of Physics, Faculty of Science, Khon Kaen University, Khon Kaen 40002, Thailand \\ ${ }^{2}$ Integrated Nanotechnology Research Center, Khon Kaen University, Khon Kaen 40002, Thailand \\ ${ }^{3}$ Nanotec-KKU Center of Excellence on Advanced Nanomaterials for Energy Production and Storage, \\ Khon Kaen 40002, Thailand \\ Correspondence should be addressed to Samuk Pimanpang; samukpi@kku.ac.th
}

Received 6 February 2015; Revised 20 April 2015; Accepted 29 October 2015

Academic Editor: Cláudia G. Silva

Copyright (C) 2016 Wasan Maiaugree et al. This is an open access article distributed under the Creative Commons Attribution License, which permits unrestricted use, distribution, and reproduction in any medium, provided the original work is properly cited.

\begin{abstract}
Multiwall carbon nanotubes (MWCNTs) were modified by acids $\left(\mathrm{H}_{2} \mathrm{SO}_{4}: \mathrm{HNO}_{3}\right)$ for generating active groups on the nanotube surface. Unmodified- and modified-carbon nanotubes were coated on the conductive glass and conductive plastic substrates by a slurry paste method, and they were used as the counter electrodes (CEs) of dye-sensitized solar cells (DSSCs). Scanning electron microscopy reveals that carbon nanotubes are evenly deposited on the conductive glass. The efficiency of the glass based DSSCs of unmodified- and modified-carbon nanotubes and Pt CEs is $\sim 4.73 \%, \sim 5.66 \%$, and $\sim 6.08 \%$, respectively. The efficiency of the plastic based DSSCs of the unmodified- and modified-carbon nanotubes CEs is $\sim 0.80 \%$ and $\sim 2.11 \%$, respectively. The voltammogram and electrochemical impedance spectroscopy results suggest that the superior performance of the modified-carbon nanotubes DSSCs is attributable to the high electrocatalytic activity and the low charge-transfer resistance of the modified-carbon nanotubes film over the unmodified-carbon nanotubes film.
\end{abstract}

\section{Introduction}

Dye-sensitized solar cell (DSSC) has been intensively studied because of its simple structure, low fabrication cost, promising light harvesting efficiency, and environmental friendliness. The high energy conversion efficiency of DSSCs is accomplished through the use of a highly porous semiconductor film coated by a monolayer dye-sensitizer as the working electrode, which was developed by O'Regan and Grätzel in 1991 [1]. $\mathrm{TiO}_{2}$ nanoparticles are commonly used as a semiconductor because they deliver the highest energy conversion efficiency among semiconductors $(\mathrm{ZnO}$, $\mathrm{Nb}_{2} \mathrm{O}_{5}, \mathrm{WO}_{3}$, and $\mathrm{SnO}_{2}$ ) [2-5]. $\mathrm{TiO}_{2}$ nanoparticles serve as the electron-transport medium between dye-sensitizers and the electron collector (transparent conductive substrate). Electrons from the electron collector will flow through the external load reaching the counter electrode and undergo the reduction with tri-iodide $\left(\mathrm{I}_{3}^{-}+2 \mathrm{e}^{-} \rightarrow 3 \mathrm{I}^{-}\right)$with the help of the catalyst film. The cell efficiency is found to be strongly related to the catalyst film (counter electrode, CE).

Platinum (Pt) film is commonly used as the DSSC counter electrode because of its good catalytic activity, but $\mathrm{Pt}$ is an expensive material. Other cheap materials have been tested as an alternative DSSC catalyst, including carbon black, carbon nanotubes, graphene, conductive polymers, and metal sulfide [6-11]. Carbon nanotubes (CNTs) are applied as the DSSC counter electrode because of their unique properties such as good catalytic activity, good conductivity, high thermal stability, high aspect ratio, and comparatively lower price than Pt. Thus, by switching to a CNT counter electrode, the DSSC production cost should be minimized. However, the 


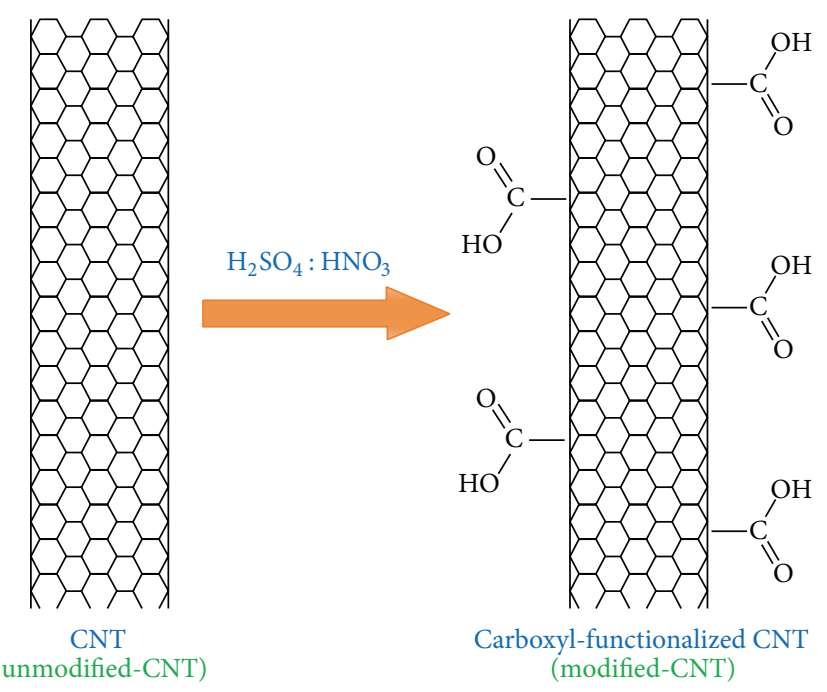

Figure 1: The formation of carboxyl groups on the acid-treated carbon nanotube surface.

performance of the CNTs based DSSCs is still low compared to the Pt DSSC performances.

It is reported that the acid treatment can introduce functional groups, hydroxyl or carboxylic, on the carbon nanotube surfaces as shown in Figure 1. The presence of these functional groups is found to enhance nanotubes' catalytic activity [12-14]. This implies that by using an acid-treated CNTs film as the DSSC counter electrode, the tri-iodide reduction rate and the cell efficiency should be optimized. Various methods, chemical vapor deposition, arc discharge, electrophoretic deposition, or slurry paste [15-20], were used for preparing carbon nanotube films. The slurry paste is a simple method to coat the low temperature carbon film. The low temperature process would allow the possible coating CNTs film on the plastic substrate for fabricating in the flexible DSSCs. The flexible DSSCs reduce the production cost and the cell weight. To assemble flexible DSSCs, $\mathrm{TiO}_{2}$ film was coated on the plastic by a high pressure compression as reported by Grinis et al. [21] and Fredin et al. [22]. To the best of our knowledge, there are few details on the effect of acid-treated carbon nanotubes on the dye-sensitized solar cell performance. In this work, we explored the possibility of using the carbon nanotube film as the DSSC counter electrode for both glass and plastic substrates, and the effect of the acid treatment on the solar cell performances was tested and discussed.

\section{Experimental}

2.1. Modification of MWCNTs. The modified-multiwall carbon nanotubes (M-CNTs) were prepared by mixed multiwall carbon nanotubes (unmodified-CNTs, U-CNTs) $5 \mathrm{~g}$ in sulfuric acid $\left(\mathrm{H}_{2} \mathrm{SO}_{4}, 95 \%\right) 30 \mathrm{~mL}$ and nitric acid $\left(\mathrm{HNO}_{3}\right.$, $63 \%) 10 \mathrm{~mL}$, then stirring for $30 \mathrm{~min}$ at room temperature. After that, the carbon nanotubes were rinsed with DI water several times, filtered with filter paper, and dried at $80^{\circ} \mathrm{C}$ for $12 \mathrm{~h}$ at the ambient conditions. After the modification, the carboxylic groups were generated on the CNT surface as shown in Figure 1.

\subsection{Preparation of $\mathrm{TiO}_{2}$ and CNT Films}

2.2.1. $\mathrm{TiO}_{2}$ Film Coated on the Conductive Glass Substrate $\left(\mathrm{TiO}_{2} / \mathrm{FTO}\right.$ ). The conductive glass (fluoride doped tin oxide glass, FTO, sheet resistance of $15 \Omega /$ sq, Solaronix) was used as a substrate for coating $\mathrm{TiO}_{2}$ films. The dense $\mathrm{TiO}_{2}$ layer was prepared by spinning the titanium diisopropoxide bis(acetylacetonate) $\left(\mathrm{C}_{16} \mathrm{H}_{28} \mathrm{O}_{6} \mathrm{Ti}\right)$ solution on the $\mathrm{FTO}$ substrate. The porous transparent $\mathrm{TiO}_{2}$ film was coated on the dense $\mathrm{TiO}_{2}$ film by a screen printing technique using the $\mathrm{TiO}_{2}$ paste PST-18NR (Catalysts \& Chemicals Ind. Co., Ltd.). A scattered $\mathrm{TiO}_{2}$ layer was coated on the porous $\mathrm{TiO}_{2}$ film by screen printing using PST-400C (Catalysts \& Chemicals Ind. Co., Ltd.). $\mathrm{TiO}_{2}$ films were annealed at $500^{\circ} \mathrm{C}$ for $1 \mathrm{~h}$ at the ambient conditions, and the postannealed $\mathrm{TiO}_{2}$ films were treated with UV light for $5 \mathrm{~min}$. The UV-treated $\mathrm{TiO}_{2}$ films were immersed in the dye solution, cis-bis(isothiocyanato) bis(2,2' -bipyridyl-4,4'-dicarboxylato)-ruthenium(II)-bistetrabutylammonium (N719, Solaronix, $5 \times 10^{-4} \mathrm{M}$ in acetonitrile : tert-butanol at a volume ratio of $1: 1)$ for $24 \mathrm{~h}$ at room temperature in the dark.

2.2.2. $\mathrm{TiO}_{2}$ Films Coated on the Conductive Plastic Substrate $\left(\mathrm{TiO}_{2} / \mathrm{ITO} / \mathrm{PEN}\right)$. The indium tin oxide coated on polyethylene naphthalate (ITO/PEN, sheet resistance of $60 \Omega / s q$, Peccell Technologies, Inc.) was used as the conductive flexible substrate. The $\mathrm{TiO}_{2}$ slurry, mixture of $5 \mathrm{~g} \mathrm{TiO}_{2}(\mathrm{P} 25,20 \mathrm{~nm}$, Degussa, Germany) in $20 \mathrm{~mL}$ isopropanol, was carefully pasted on the ITO/PEN substrate and let it dry in the air. Then, $\mathrm{TiO}_{2}$ films were pressed by the hydraulic pressuring system (Model HP-10, T.M.C. Industrial Co., Ltd.) at the compression pressure of $\sim 510 \mathrm{MPa}$, called pressed $\mathrm{TiO}_{2}$ film. The pressed $\mathrm{TiO}_{2}$ films were immersed in the N719 dye solution, $5 \times 10^{-4} \mathrm{M}$ in acetonitrile : tert-butanol at a volume ratio of $1: 1$, for $24 \mathrm{~h}$ at room temperature in the dark.

2.2.3. CNT Films. CNT film was deposited on the conductive glass (CNT/FTO) or conductive plastic (CNT/ITO/PEN) substrates by the slurry paste method. The carbon slurry was a mixture of $0.6 \mathrm{~g}$ M-CNTs (or $0.6 \mathrm{~g} \mathrm{U}-\mathrm{CNTs}$ ) and $0.1 \mathrm{~g}$ PVDF in $3 \mathrm{~mL} \mathrm{~N}$-methyl-2-pyrrolidione (NMP). The carbon slurry was stirred by the magnetic stirrer for $30 \mathrm{~min}$. The slurry was pasted on the substrate by a glass rod, and then films were dried at $80^{\circ} \mathrm{C}$ for $6 \mathrm{~h}$.

2.3. DSSC Assemble. The glass based DSSC was assembled by using dye- $\mathrm{TiO}_{2} /$ FTO film as the working electrode and CNT/FTO film as the counter electrode with the cell active area of $0.7 \times 0.7 \mathrm{~cm}^{2}$. These two electrodes were sandwiched together with two layers of a $60 \mu \mathrm{m}$ thick Surlyn polymer film (Solaronix) as a plastic sealant and a cell spacer. Two Surlyn layers were applied because of the thick carbon film. A liquid electrolyte, a mixture of $0.6 \mathrm{M}$ MPI (1-methyl-3propylimidazolium iodide), $0.1 \mathrm{M} \mathrm{LiI}$ (lithium iodide anhydrous), $0.05 \mathrm{M} \mathrm{I}_{2}$ (iodide), $0.5 \mathrm{M}$ TBP (tert-butylpyridine), 
and $0.0025 \mathrm{M} \mathrm{LiCO}_{3}$ (lithium carbonate) in acetonitrile, was filled into the cell through the drilled hole on the counter electrode. After electrolyte filling, the hole was sealed by a Surlyn polymer film covered with a small piece of glass slide.

In case of the flexible DSSCs, the dye-pressed- $\mathrm{TiO}_{2} /$ ITO/PEN films and the CNT/ITO/PEN films were used as the working electrode and the counter electrode, respectively, with the cell active area of $0.7 \mathrm{~cm} \times 0.7 \mathrm{~cm}$. Three layers of a $60 \mu \mathrm{m}$ thick Surlyn film were placed between these two electrodes as a cell spacer and then tightly clipped. The liquid electrolyte was filled into these flexible cells.

2.4. Film Characterization. The film morphology and the film thickness were characterized by scanning electron microscope (SEM, LEO, SEM 1450VP, UK). The amount of adsorbed dye was estimated using a UV-visible spectrometer (UV-160A, Shimadzu) by desorbing dye molecules from $\mathrm{TiO}_{2}$ films in the $10 \mathrm{~mL}$ solution of a mixed $0.1 \mathrm{M} \mathrm{NaOH}$ and ethanol at a volume ratio $1: 1$. XPS measurement was carried out at Beamline 3.2a, SLRI, with maximum photon energy of $650 \mathrm{eV}$, kinetic energy step of $0.1 \mathrm{eV}$, and pass energy of $100 \mathrm{eV}$. Before XPS measurement, the $\mathrm{Au} 4 \mathrm{f}$ peak was used to calibrate energy shift from the instrument. The XPS was operated under the pressure of $\sim 10^{-10} \mathrm{mbar}$ and the temperature at $25^{\circ} \mathrm{C}$. The cyclic voltammetry $(\mathrm{CV})$ was measured in a three-compartment cell with Gamry Instrument Reference 3000 (Gamry, USA) at a scan rate of $20 \mathrm{mV} / \mathrm{s}$. The Pt plate (area $\sim 0.385 \mathrm{~cm}^{2}$ ) and the $\mathrm{Ag} / \mathrm{AgCl}$ electrode were used as the counter electrode and the reference electrode, respectively. The Pt and carbon films were taped with an insulating tape with an open area of $0.25 \mathrm{~cm}^{2}$ prior to the CV scan. The electrochemical impedance spectroscopy (EIS) was recorded using Gamry Instrument Reference 3000 Potentiostat (Gamry, USA) under a light intensity of $100 \mathrm{~mW} \cdot \mathrm{cm}^{-2}$ with frequency from $0.01 \mathrm{~Hz}$ to $100,000 \mathrm{~Hz}$ and AC amplitude of $10 \mathrm{mV}$. The cell performance was measured with a super solar simulator (Wacom, Class A) system under a light intensity of $100 \mathrm{~mW} \cdot \mathrm{cm}^{-2}$.

\section{Results and Discussion}

3.1. Glass Based DSSCs. The surface morphology of $\mathrm{TiO}_{2}$ films coated on the conductive glass is characterized by SEM, and images are presented in Figure 2. The SEM results show that $\mathrm{TiO}_{2}$ films have the porous structures. The cross section image of $\mathrm{TiO}_{2}$ film (Figure 2(b)) clearly shows three different layers: (1) a dense- $\mathrm{TiO}_{2}$ layer $\sim 0.5 \mu \mathrm{m},(2)$ a porous transparent $\mathrm{TiO}_{2}$ layer $\sim 5.5 \mu \mathrm{m}$, and (3) a scattered $\mathrm{TiO}_{2}$ layer $\sim 3.2 \mu \mathrm{m}$. The amount of dye molecules adsorbed on the $\mathrm{TiO}_{2}$ films, on a $\mathrm{TiO}_{2}$ area of $0.49 \mathrm{~cm}^{2}$, was desorbed and analyzed by the UV-visible spectrometer. All three absorbance spectra in Figure 2(c) exhibit close absorbance value, implying that the $\mathrm{TiO}_{2}$ thickness of these three films is close to one another. The amount of dye loaded on the $\mathrm{TiO}_{2}$ films is calculated via the following equations:

$$
\begin{aligned}
A_{\lambda} & =\varepsilon_{\lambda} c l, \\
M & =c V,
\end{aligned}
$$

where $A_{\lambda}$ and $\varepsilon_{\lambda}$ are the absorbance value and the specific absorbance $\left(\mathrm{M}^{-1} \mathrm{~cm}^{-1}\right)$ as a function of wavelength, respectively. $c$ is the desorbed dye concentration (M), $l$ is the thickness of the standard cuvette glass $(1 \mathrm{~cm}), V$ is the volume of the dye solution $(10 \mathrm{~mL})$, and $M$ is the amount of dye molecules adsorbed on the $\mathrm{TiO}_{2}$ films (mol). By using the specific absorbance at $\lambda=300 \mathrm{~nm}, \varepsilon_{300}=5.7 \times 10^{4} \mathrm{M}^{-1} \mathrm{~cm}^{-1}$, the amount of dye molecules is about $10.86 \times 10^{-8}, 10.71 \times$ $10^{-8}$, and $9.92 \times 10^{-8} \mathrm{~mol} / \mathrm{cm}^{2}$ (average $10.50 \times 10^{-8} \pm 0.51 \times$ $10^{-8} \mathrm{~mol} / \mathrm{cm}^{2}$ ).

To verify the formation of carboxylic groups on the CNTs' surface, X-ray photoelectron spectroscopy (XPS) was scanned on the unmodified-CNTs (U-CNTs) and modifiedCNTs (M-CNTs). The XPS survey spectra of U-CNTs and M-CNTs powders in Figure 3(a) mainly contain oxygen and carbon peaks. It is shown in Table 1 that the $\mathrm{O} / \mathrm{C}$ area ratio increases from 0.75 to 0.89 after the acid treatment, implying formation of the oxygen functional groups on the modified nanotube surface. To see the change on M-CNTs, the C 1 s peaks were deconvoluted as shown in Figure 3(b). The binding energy of each bond is listed in Table 1. It is observed that the U-CNTs consist of three bonds $(\mathrm{C}-\mathrm{C}, \mathrm{C}-\mathrm{OH}$, and C$\mathrm{O}-\mathrm{C}$ bonds), but M-CNTs are composed of four bonds. The extra peak at $289.3 \mathrm{eV}$ was detected, which corresponds to $\mathrm{C}=\mathrm{O}$ (carboxylic groups). This clearly confirms the presence of the functional groups on the acid-treated CNTs.

The optical images of U-CNTs and M-CNTs films in Figure 4 show the similar structures between these two films. However, the low magnification SEM images (Figure 4) reveal the great differences. The modified film seems to have a better nanotube spreading than the unmodified film. This may be due to the functional groups interacting to the FTO surface $[23,24]$. The film thickness estimated from the cross section SEM images (Figure $4(\mathrm{~d})$ ) is $\sim 33-65 \mu \mathrm{m}$. The CNTs films were used as the DSSC counter electrode, and the cell efficiency was analyzed by the solar simulator. The short-circuit current density $\left(J_{\text {sc }}\right)$, open-circuit voltage $\left(V_{\mathrm{oc}}\right)$, fill factor $(\mathrm{FF})$, and efficiency $(\eta)$ were extracted from the $J-V$ curves of Figure 5(a) and listed in Table 2. M-CNTs DSSC (5.66\%) produces larger efficiency than that of UCNTs DSSC (4.73\%). This could be due to the presence of carboxylic groups on CNTs' surface strengthening the nanotube reactivity as observed by many groups [12-14]. Compared to Suzuki et al. [7], Ahn et al. [8], and Sedghi and Miankushki [25] works, they obtained the efficiency of the carbon nanotube based DSSCs of 3.5\%, 5.18\% (prepared by aerosol deposition process), and $6.7 \%$ (prepared by spraying method), respectively. Our efficiency is between these values.

To explain the different cell behaviors, cyclic voltammetry (CV) was conducted on these three films at the scan rate of $20 \mathrm{mV} / \mathrm{s}$ in the $10 \mathrm{mM} \mathrm{LiI}, 1 \mathrm{mM} \mathrm{I}_{2}$, and $0.1 \mathrm{M} \mathrm{LiClO}_{4}$ electrolyte. The CV curve of Pt film (Figure 5(b)) exhibits two oxidation peaks at $0.34 \mathrm{~V}$ and $0.71 \mathrm{~V}$ and two reduction peaks at $0.02 \mathrm{~V}$ and $0.50 \mathrm{~V}$. Similarly, M-CNTs film is composed of two oxidation peaks at 0.33 and $0.76 \mathrm{~V}$ and two reduction peaks at -0.05 and $0.49 \mathrm{~V}$. In contrast, U-CNTs films do not manifest clear oxidation or reduction peaks. The $\mathrm{CV}$ current density of M-CNT film is higher than that of U-CNT 


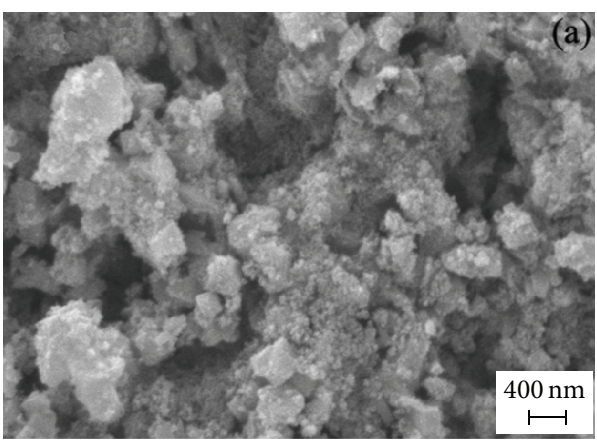

(a)
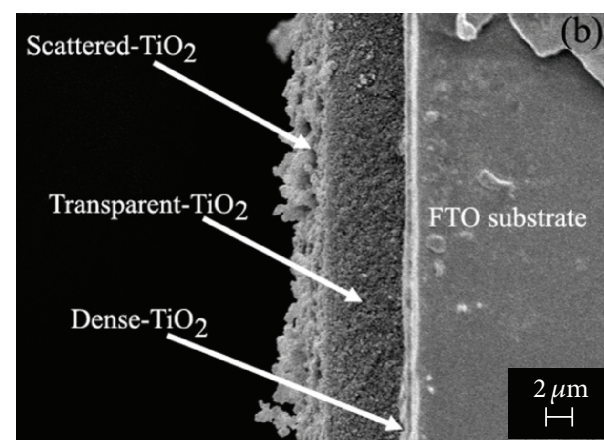

(b)

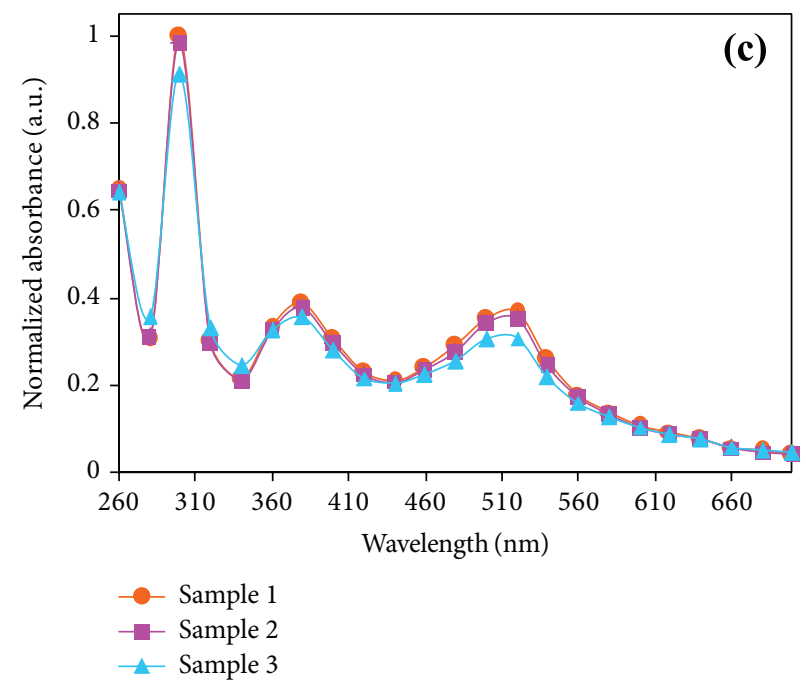

(c)

Figure 2: (a) The top and (b) cross section SEM images of $\mathrm{TiO}_{2}$ film on FTO glass. (c) The absorbance spectra of the desorbed dye solutions of the $\mathrm{TiO}_{2} / \mathrm{FTO}$ films.

TABLE 1: Summary of the peak positions and the O/C area ratio of U-CNTs and M-CNTs from XPS measurement.

\begin{tabular}{lcccccc}
\hline Sample & \multicolumn{3}{c}{ Relative amount of elements (\%) } & \multicolumn{3}{c}{ Binding energy (eV) } \\
& $\mathrm{O}$ & $\mathrm{C}$ & $\mathrm{O} / \mathrm{C}$ & $\begin{array}{c}\text { Peak 1 } \\
\text { C-C }\end{array}$ & $\begin{array}{c}\text { Peak 2 } \\
-\mathrm{C}-\mathrm{OH}\end{array}$ & $\begin{array}{c}\text { Peak 3 } \\
\text { C-O-C }\end{array}$ \\
\hline $\begin{array}{l}\text { Unmodified-CNTs } \\
\text { (U-CNTs) }\end{array}$ & 57 & 43 & 0.75 & 284.1 & 286 & 288 \\
\hline $\begin{array}{l}\text { Modified-CNTs } \\
\text { (M-CNTs) }\end{array}$ & 53 & 47 & 0.89 & 284.2 & 285.5 & 287.6 \\
\hline
\end{tabular}

TABLE 2: Summary of the interface charge-transfer resistance at the CE/electrolyte interface $\left(R_{\mathrm{ct1}}\right)$ and at the $\mathrm{TiO}_{2} /$ dye/electrolyte interface $\left(R_{\mathrm{c} 2}\right)$, the series resistance $\left(R_{s}\right)$, open-circuit voltage $\left(V_{\mathrm{oc}}\right)$, short-circuit current density $\left(J_{\mathrm{sc}}\right)$, fill factor $(\mathrm{FF})$, and efficiency $(\eta)$ of $\mathrm{U}-\mathrm{CNTs}$, $\mathrm{M}-\mathrm{CNT}$, and Pt glass DSSCs.

\begin{tabular}{|c|c|c|c|c|c|c|c|}
\hline Counter electrode & $R_{s}(\mathrm{Ohm})$ & $R_{\mathrm{ct} 1}(\mathrm{Ohm})$ & $R_{\mathrm{ct} 2}(\mathrm{Ohm})$ & $V_{\mathrm{oc}}(\mathrm{V})$ & $J_{\mathrm{sc}}\left(\mathrm{mA} / \mathrm{cm}^{2}\right)$ & FF & $\eta(\%)$ \\
\hline $\begin{array}{l}\text { Unmodified-CNTs } \\
\text { (U-CNTs/FTO/glass) }\end{array}$ & 17 & 34 & 60 & 0.78 & 9.91 & 0.61 & 4.73 \\
\hline $\begin{array}{l}\text { Modified-CNTs } \\
\text { (M-CNTs/FTO/glass) }\end{array}$ & 14 & 19 & 61 & 0.73 & 12.70 & 0.61 & 5.66 \\
\hline $\begin{array}{l}\text { Pt sputter } \\
\text { (Pt/FTO/glass) }\end{array}$ & 16 & 3 & 60 & 0.76 & 10.02 & 0.80 & 6.08 \\
\hline
\end{tabular}




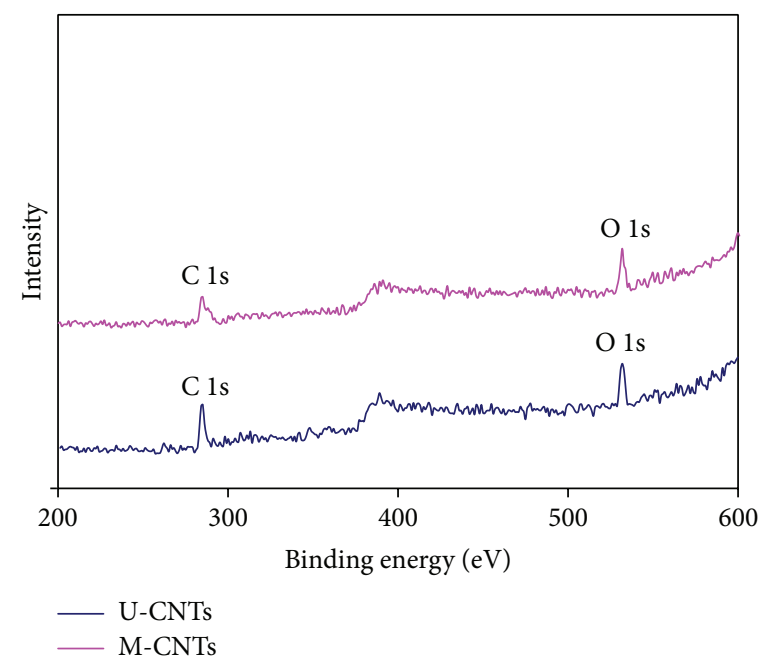

(a)

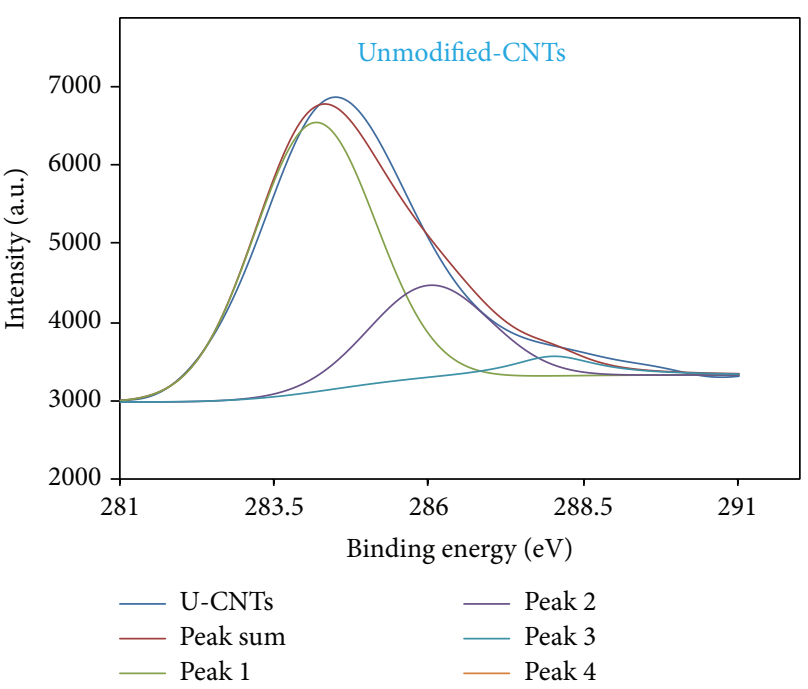

(b)

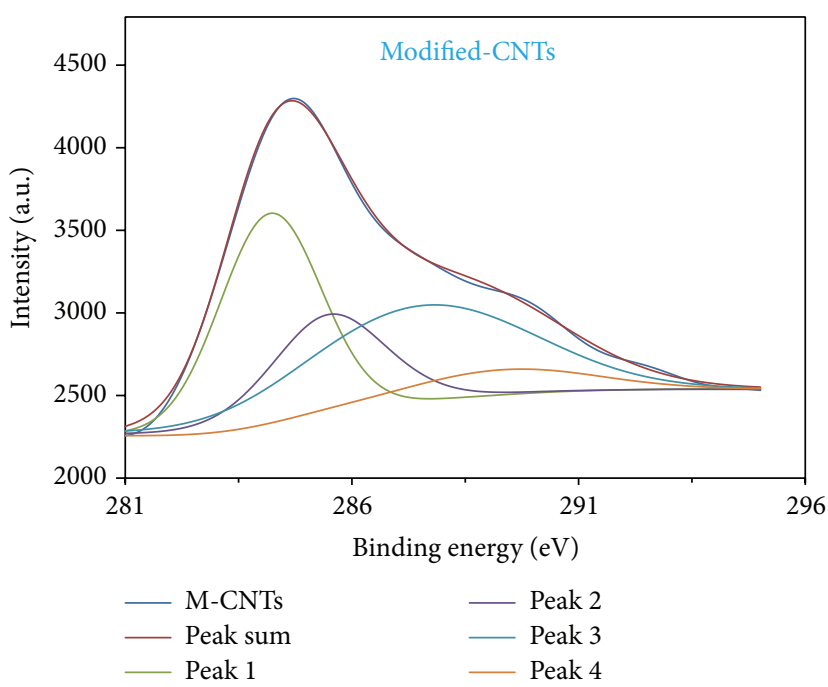

(c)

FIGURE 3: (a) XPS survey spectra of unmodified-carbon nanotubes (U-CNTs) and modified-carbon nanotubes (M-CNTs), C1s spectra of (b) U-M-CNTs.

film, implying the superior electrocatalytic activity performance of M-CNTs film above the U-CNTs. Electrochemical impedance spectroscopy (EIS) was also measured under the light intensity of $100 \mathrm{~mW} / \mathrm{cm}^{2}$ and the EIS spectra are shown in Figure 6(b). EIS spectra consist of two semicircles similar to the literatures $[26,27]$. The equivalent circuit in Figure 6(a) is used to fit the EIS curves. The equivalent circuit is comprised of an interface charge-transfer resistance $\left(R_{\mathrm{ct}}\right)$, a constant phase element (CPE), and a series resistance $\left(R_{s}\right)$. The CPE reflects the interfacial capacitance, with $\mathrm{CPE}_{1}$ and $\mathrm{CPE}_{2}$ being constant phase elements of the $\mathrm{CE} /$ electrolyte interface and the $\mathrm{TiO}_{2}$ /dye/electrolyte interface, respectively. $R_{\mathrm{ct} 1}$ and $R_{\mathrm{ct} 2}$ are the electron-transfer resistances at the $\mathrm{CE} /$ electrolyte interface and at the $\mathrm{TiO}_{2} /$ dye/electrolyte interface, respectively. $R_{\mathrm{ct} 1}$ of U-CNTs and M-CNTs DSSCs is $\sim 34 \Omega$ and $\sim 19 \Omega$, respectively, as listed in Table 2. $R_{\mathrm{ctl}}$ of MCNTs film is smaller than that of U-CNTs film because MCNTs film has a better spreading and stronger attaching to the glass substrate than U-CNTs film.

3.2. Plastic Based DSSCs. Figures 7(a) and 7(b) show the optical images of the unpressed and pressed $\mathrm{TiO}_{2}$ films on the conductive plastic (ITO/PEN), respectively. It observes that the pressed $\mathrm{TiO}_{2}$ film is brighter than the unpressed film, which is attributed to the densely packed $\mathrm{TiO}_{2}$ nanoparticles after compressing. The thickness of the pressed $\mathrm{TiO}_{2}$ film, estimated from the cross section SEM in Figure 7(d), is $\sim 2.1 \mu \mathrm{m}$. It is worth mentioning that we had tried to prepare the thicker $\mathrm{TiO}_{2}$ film, but $\mathrm{TiO}_{2}$ film was peeled of the 

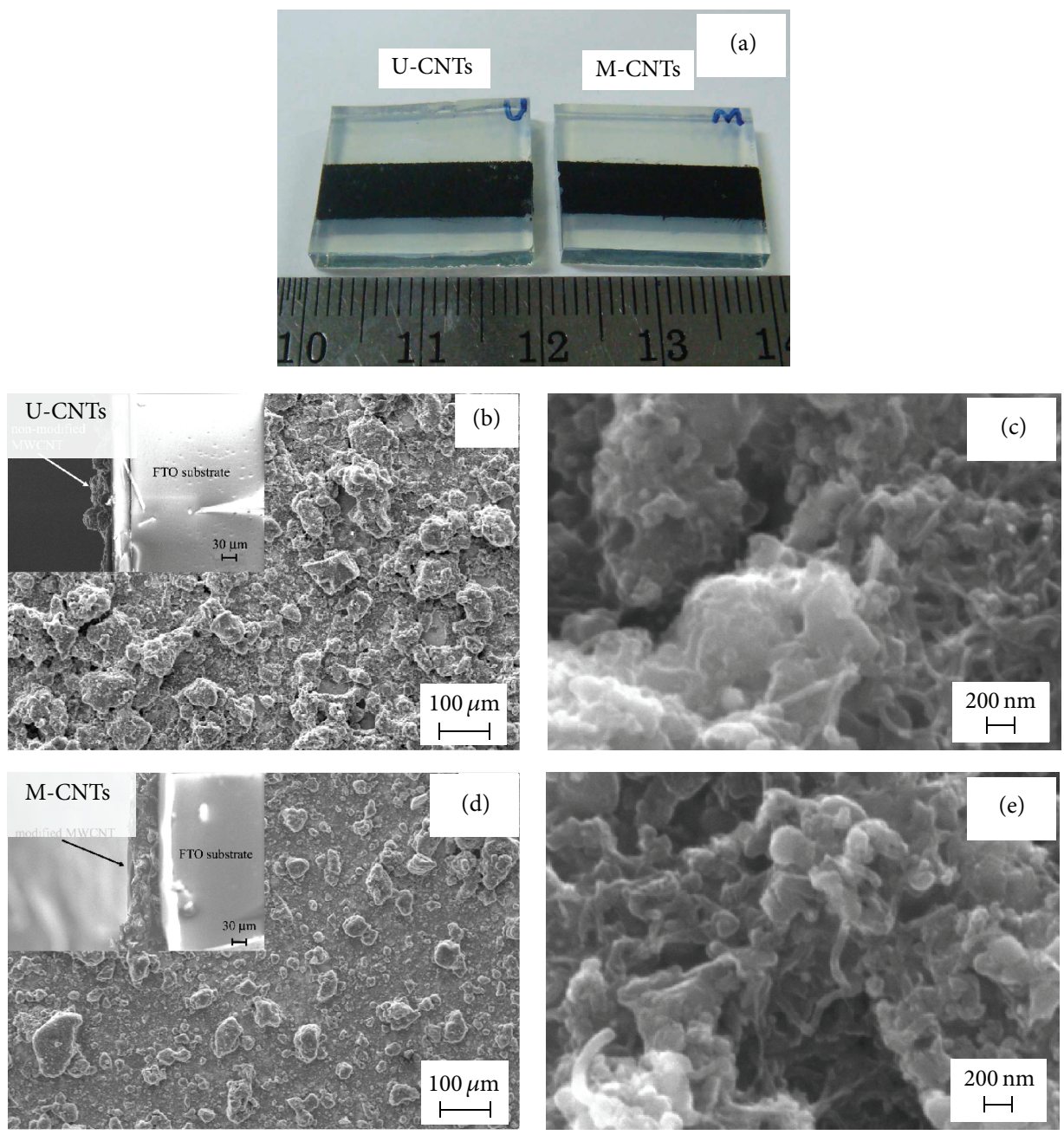

FIgURE 4: (a) The optical image of U-CNTs and M-CNTs films coated on the conductive glass. (b) Low and (c) high magnification SEM images of U-CNTs film coated on the conductive glass. (d) Low and (e) high magnification SEM images of M-CNTs film coated on the conductive glass.

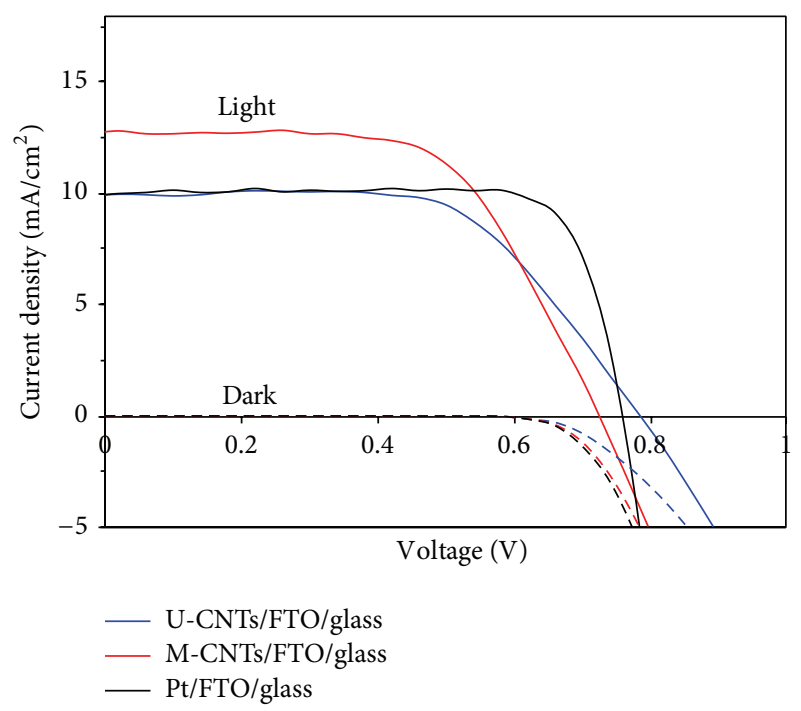

(a)

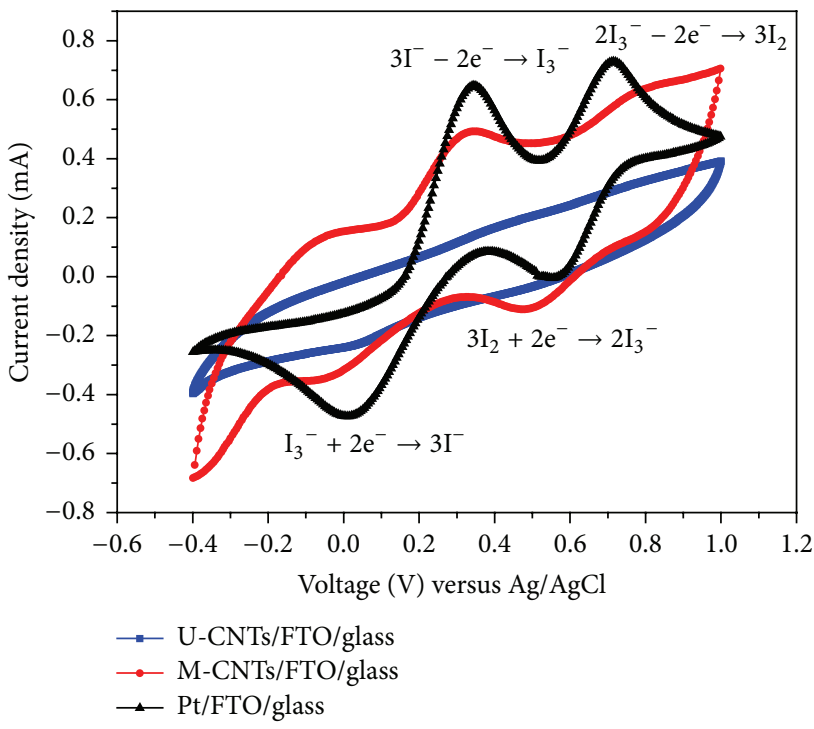

(b)

Figure 5: (a) Plot of the photocurrent density $(J)$ versus the photovoltage $(V)$ of the Pt/FTO, U-CNTs/FTO, and M-CNTs/FTO glass DSSCs.

(b) Cyclic voltammograms of the Pt/FTO, U-CNTs/FTO, and M-CNTs/FTO films on glass substrates in acetonitrile solution of $10 \mathrm{mM}$ LiI, $1 \mathrm{mM} \mathrm{I}_{2}$, and $0.1 \mathrm{M} \mathrm{LiClO}_{4}$ at the scan rate of $20 \mathrm{mV} / \mathrm{s}$. 


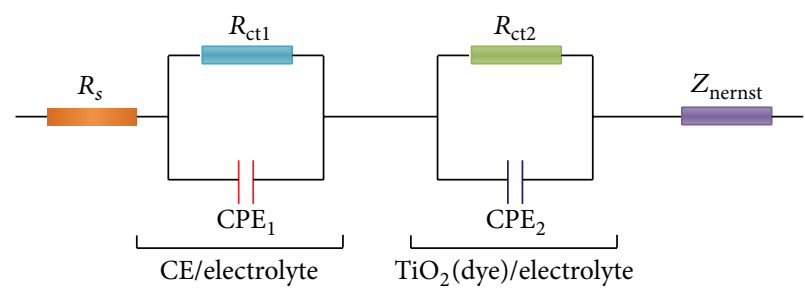

(a)

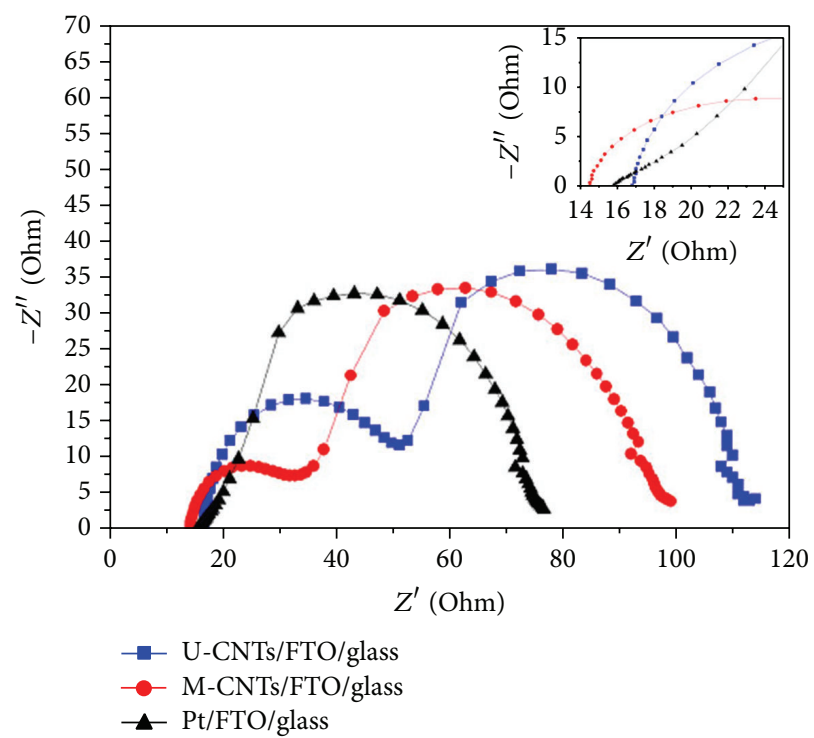

(b)

FIGURE 6: (a) The equivalent circuit of glass DSSCs and (b) Nyquist plots of the Pt/FTO, U-CNTs/FTO, and M-CNTs/FTO DSSCs.

substrate after the film compression. The low amount of $\mathrm{TiO}_{2}$ paste on the plastic substrate was found to well attach to the substrate.

The amount of dye loaded on the pressed $\mathrm{TiO}_{2}$ films is analyzed by UV-visible spectrometer, and the result is presented in Figure 7(e). Three absorbance spectra show the close absorbance value, meaning that the thicknesses of the pressed $\mathrm{TiO}_{2}$ films are quite closed. By using (1) and $\varepsilon_{300}=$ $5.7 \times 10^{4} \mathrm{M}^{-1} \mathrm{~cm}^{-1}$, the average amount of dye coated on the pressed $\mathrm{TiO}_{2} / \mathrm{ITO} / \mathrm{PEN}$ films is $\sim 5.69 \times 10^{-8} \pm 0.41 \times$ $10^{-8} \mathrm{~mol} / \mathrm{cm}^{2}$. As expected, the amount of dye loaded on the $\mathrm{TiO}_{2} / \mathrm{ITO} / \mathrm{PEN}$ films is much less than that of the $\mathrm{TiO}_{2} / \mathrm{FTO}$ films by $\sim 46 \%$. This is due to the thinner press $\mathrm{TiO}_{2}$ film $(\sim 2.1 \mu \mathrm{m})$ than that of the screened $\mathrm{TiO}_{2}$ film $(\sim 9.2 \mu \mathrm{m})$, as seen in Figures 7(d) and 2(b), respectively.

CNTs films were coated on the ITO/PEN films via the same procedure on the $\mathrm{CNTs} / \mathrm{FTO} /$ glass films. The low magnification SEM images of U-CNTs and M-CNTs films, Figures $8(\mathrm{a})$ and $8(\mathrm{c})$, display the great differences. M-CNTs are found to well spread on the plastic surface, but U-CNTs form the island-like structures on the ITO/PEN surface. The well depositing of M-CNTs on the ITO/PEN surface should be attributed to the good interaction between the functional groups to the ITO surface $[23,24]$.

The performance of the flexible DSSCs, using dye/ pressed- $-\mathrm{TiO}_{2} / \mathrm{ITO} / \mathrm{PEN}$ film as the working electrode and $\mathrm{CNTs} / \mathrm{ITO} / \mathrm{PEN}$ film as the counter electrode, is tested under the same condition with the glass based DSSCs. $J_{\mathrm{sc}}, V_{\mathrm{oc}}$, FF, and $\eta$ are extracted from Figure 9(a) and summarized in Table 3. The Pt flexible DSSC has the largest efficiency as observed in the glass based DSSCs. The efficiency of MCNTs flexible DSSC $(\sim 2.31 \%)$ is higher than the U-CNTs flexible DSSC ( 1.11\%). CV curves in Figure 9(b) suggest that the M-CNTs/plastic film generates the better electrocatalytic
TABLE 3: Summary of $V_{\mathrm{oc}}, J_{\mathrm{sc}}$, FF, and $\eta$ of U-CNTs, M-CNTs, and Pt plastic DSSCs.

\begin{tabular}{lcccc}
\hline Counter electrode & $V_{\mathrm{oc}}(\mathrm{V})$ & $J_{\mathrm{sc}}\left(\mathrm{mA} / \mathrm{cm}^{2}\right)$ & $\mathrm{FF}$ & $\eta(\%)$ \\
\hline $\begin{array}{l}\text { Unmodified-CNTs } \\
\text { (U-CNTs/ITO/PEN) }\end{array}$ & 0.72 & 4.93 & 0.31 & 1.11 \\
\hline $\begin{array}{l}\text { Modified-CNTs } \\
\text { (M-CNTs/ITO/PEN) }\end{array}$ & 0.76 & 6.03 & 0.51 & 2.31 \\
\hline $\begin{array}{l}\text { Pt sputter } \\
\text { (Pt/ITO/PEN) }\end{array}$ & 0.76 & 6.37 & 0.57 & 2.67 \\
\hline
\end{tabular}

activity than that of the U-CNTs film. Two possible factors limiting the U-CNTs catalytic activity are a low amount of CNTs coated on the ITO/PEN substrate and no carboxylic group presented on the nanotube surface. Comparing to the glass based DSSCs, the efficiency of the flexible solar cells is poorer than those of the glass based DSSCs. Three factors that minimize the flexible DSSC performances are (1) the higher sheet resistance of the conductive plastic $(60 \Omega / s q)$ than that of the conductive glass $(15 \Omega / \mathrm{sq})$, (2) the thinner $\mathrm{TiO}_{2} /$ ITO/PEN film $(\sim 2.1 \mu \mathrm{m})$ than that of the $\mathrm{TiO}_{2} / \mathrm{FTO}$ film $(\sim 9.2 \mu \mathrm{m})$, and (3) the less amount of dye loading on the $\mathrm{TiO}_{2} / \mathrm{ITO} / \mathrm{PEN}$ film $\left(\sim 5.69 \times 10^{-8} \mathrm{~mol} / \mathrm{cm}^{2}\right)$ than that of the $\mathrm{TiO}_{2} /$ FTO film $\left(\sim 10.50 \times 10^{-8} \mathrm{~mol} / \mathrm{cm}^{2}\right)$.

\section{Conclusion}

The low temperature carbon nanotube film was coated on the conductive glass and conductive plastic substrates, and they exhibit the potential application as the DSSC counter electrode. The efficiency of the M-CNTs glass and plastic based DSSCs is $\sim 5.66 \%$ and $\sim 2.11 \%$, respectively, which is larger than those of the U-CNTs glass and plastic based DSSCs 


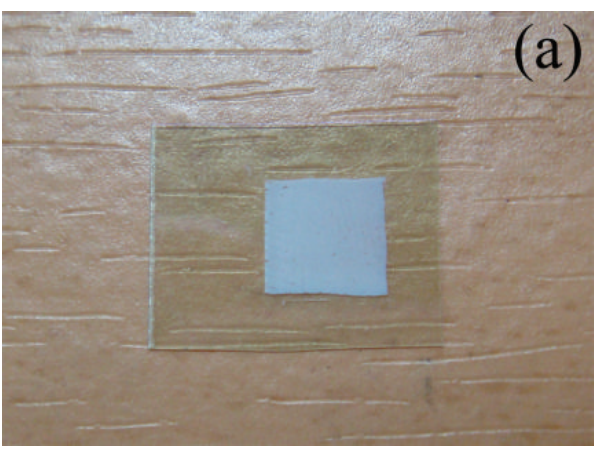

(a)

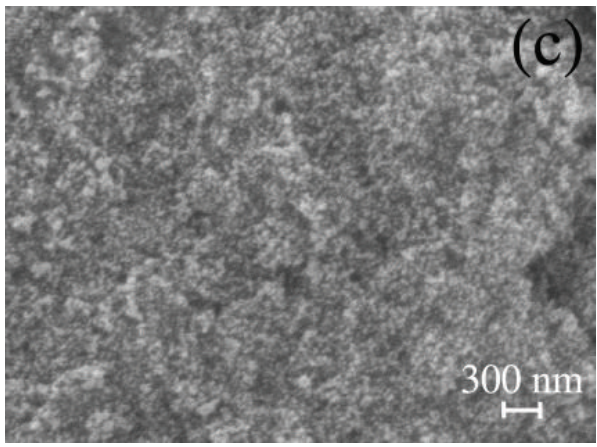

(c)

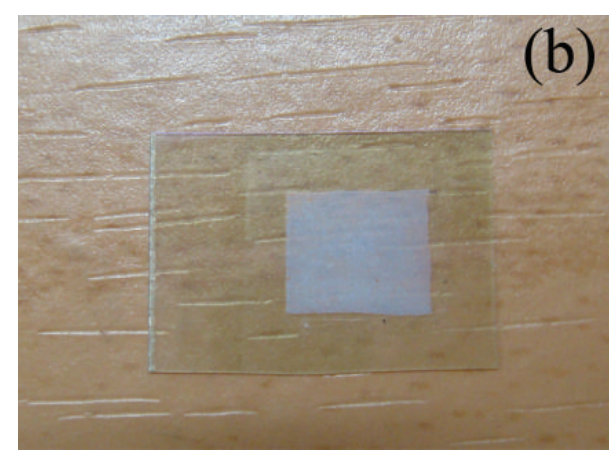

(b)

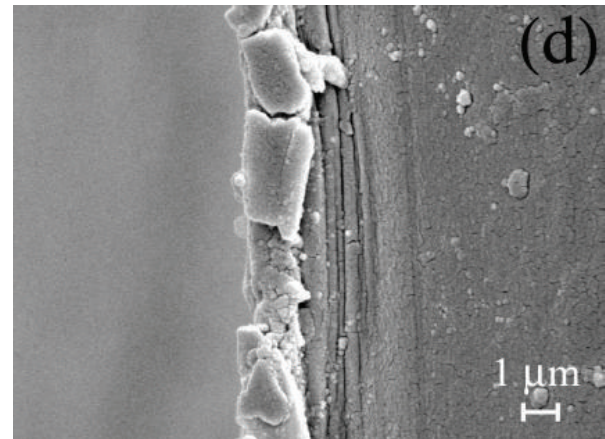

(d)

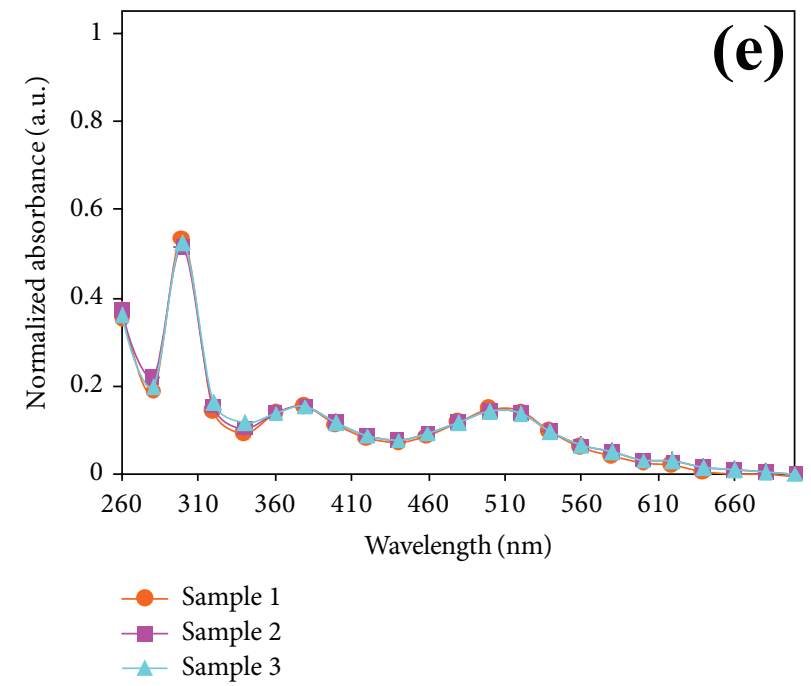

(e)

FIgure 7: The optical image of (a) the unpressed $\mathrm{TiO}_{2} / \mathrm{ITO} / \mathrm{PEN}$ film and (b) the pressed $\mathrm{TiO}_{2} / \mathrm{ITO} / \mathrm{PEN}$ film. (c) The top and (d) cross section SEM images of the pressed $\mathrm{TiO}_{2} / \mathrm{ITO} / \mathrm{PEN}$ film. (e) Absorbance spectra of the desorbed dye solutions of the pressed TiO $2 / \mathrm{ITO} / \mathrm{PEN}$ films.

which are $\sim 4.73 \%$ and $\sim 1.11 \%$, respectively. This is because $\mathrm{M}$-CNTs are surrounded by the active carboxylic groups on the surfaces and are well connected to the substrates, leading to the high film electrocatalytic activity and the low chargetransfer resistance as evidenced by CV and EIS, respectively.

\section{Conflict of Interests}

The authors declare that there is no conflict of interests regarding the publication of this paper.

\section{Acknowledgments}

This work receive scholarship under the the Post-doctoral Program from Research Affairs and Graduate School, Khon Kaen University (58227). This work was supported by the Thailand Research Fund through The Royal Golden Jubilee Ph.D. Program (PHD/0080/2554), by the Thailand Research Fund and Khon Kaen University (RSA5880035), by the Nanotechnology Center (NANOTEC), NSTDA, Ministry of Science and Technology, Thailand, through its program of 

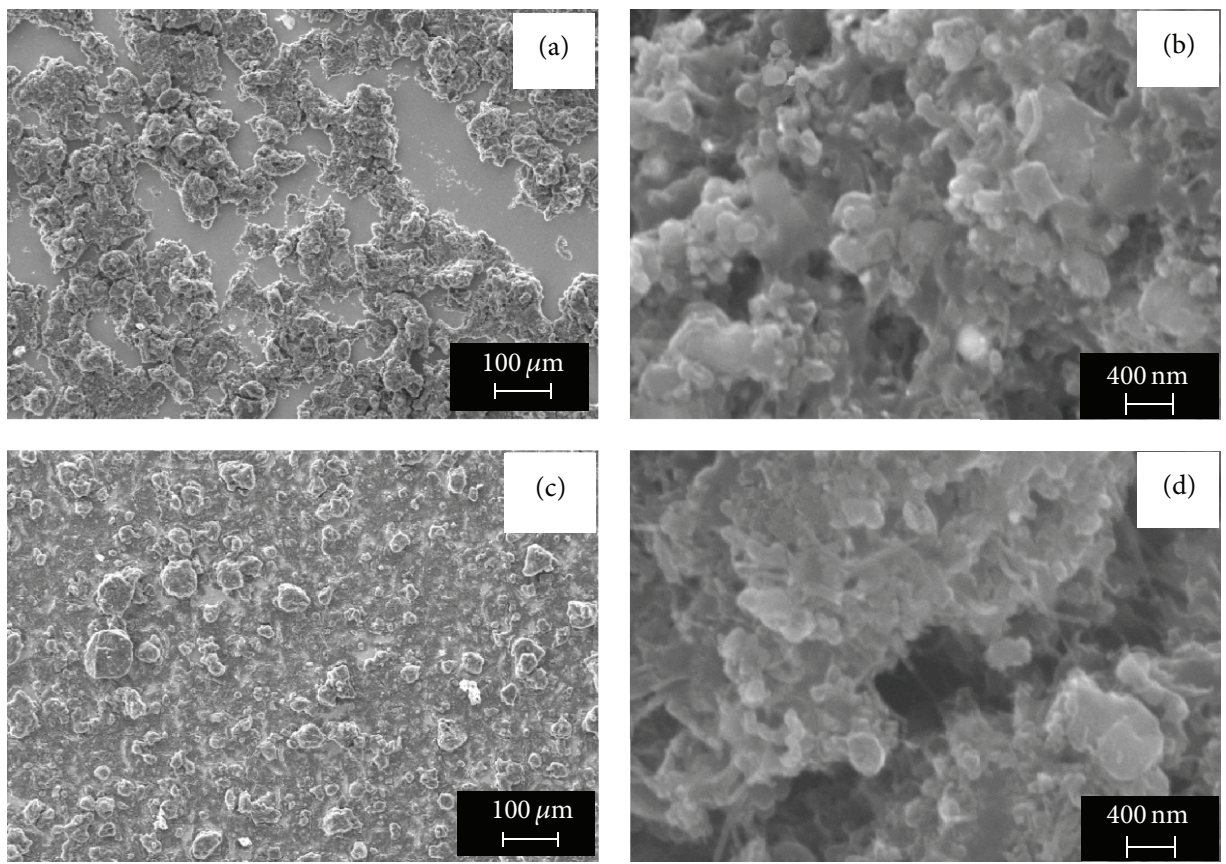

FIgURE 8: (a) The low and (b) the high magnification SEM images of the U-CNTs/ITO film. (c) The low and (d) the high magnification SEM images of the M-CNTs/ITO film coated on the conductive plastic.

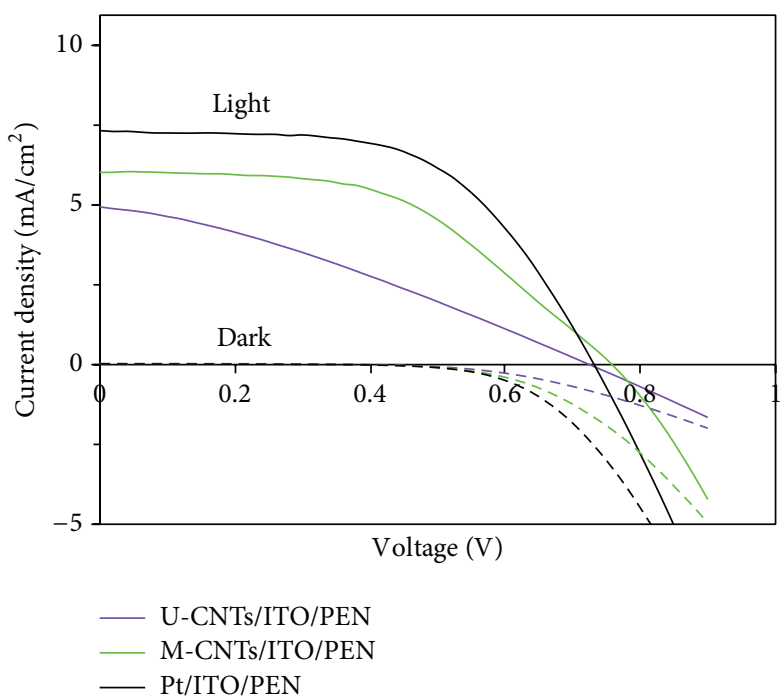

(a)

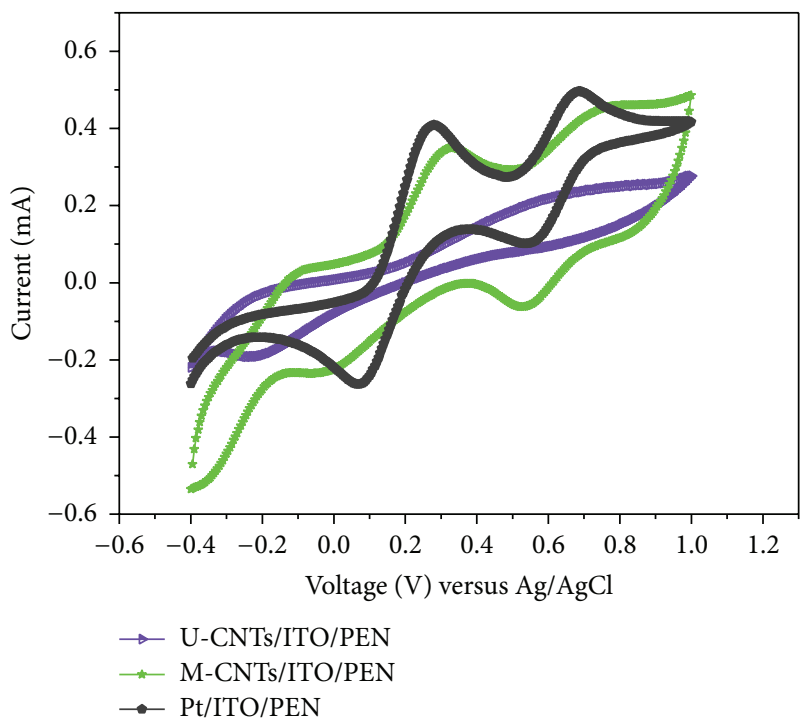

(b)

Figure 9: (a) $J-V$ curve of flexible DSSCs of the Pt/ITO, U-CNTs/ITO, and M-CNTs/ITO CEs. (b) CV curves of the Pt/ITO, U-CNTs/ITO, and M-CNTs/ITO films in acetonitrile solution of $5 \mathrm{mM} \mathrm{LiI,} 1 \mathrm{mM} \mathrm{I}_{2}$, and $0.1 \mathrm{M} \mathrm{LiClO}_{4}$ at the scan rate of $20 \mathrm{mV} / \mathrm{s}$.

Center of Excellence Network, Center for Alternative Energy Research and Development, Khon Kaen University, by the Integrated Nanotechnology Research Center, Khon Kaen University, by the Higher Education Research Promotion and National Research University Project of Thailand, Office of the Higher Education Commission, through the Advanced Functional Materials Cluster of Khon Kaen University, and by the Thailand Center of Excellence in Physics, CHE, Ministry of Education, Bangkok, and Energy Policy and Planning Office, Ministry of Energy, Bangkok, Thailand.

\section{References}

[1] B. O’Regan and M. Grätzel, "A low-cost, high-efficiency solar cell based on dye-sensitized colloidal $\mathrm{TiO}_{2}$ films," Nature, vol. 353, no. 6346, pp. 737-740, 1991. 
[2] W.-C. Chang, Y.-Y. Cheng, W.-C. Yu, Y.-C. Yao, C.-H. Lee, and H.-H. Ko, "Enhancing performance of $\mathrm{ZnO}$ dye-sensitized solar cells by incorporation of multiwalled carbon nanotubes," Nanoscale Research Letters, vol. 7, pp. 1-19, 2012.

[3] D. Maheswari and P. Venkatachalam, "Enhanced performance of bi-layer $\mathrm{Nb}_{2} \mathrm{O}_{5}$ coated $\mathrm{TiO}_{2}$ nanoparticles/nanowires composite photoanode in dye-sensitized solar cells," Photonics and Nanostructures-Fundamentals and Applications, vol. 12, no. 5, pp. 515-526, 2014.

[4] S.-M. Yong, T. Nikolay, B. T. Ahn, and D. K. Kim, "Onedimensional $\mathrm{WO}_{3}$ nanorods as photoelectrodes for dyesensitized solar cells," Journal of Alloys and Compounds, vol. 547, pp. 113-117, 2013.

[5] G. Shang, J. Wu, S. Tang, L. Liu, and X. Zhang, "Enhancement of photovoltaic performance of dye-sensitized solar cells by modifying tin oxide nanorods with titanium oxide layer," The Journal of Physical Chemistry C, vol. 117, no. 9, pp. 4345-4350, 2013.

[6] X. Zhang, J. Zhang, Y. Cui, J. Feng, and Y. Zhu, "Carbon/polymer composite counter-electrode application in dyesensitized solar cells," Journal of Applied Polymer Science, vol. 128, no. 1, pp. 75-79, 2013.

[7] K. Suzuki, M. Yamaguchi, M. Kumagai, and S. Yanagida, "Application of carbon nanotubes to counter electrodes of dyesensitized solar cells," Chemistry Letters, vol. 32, no. 1, pp. 28-29, 2003.

[8] J. Y. Ahn, J. H. Kim, J. M. Kim, D. Lee, and S. H. Kim, "Multiwalled carbon nanotube thin films prepared by aerosol deposition process for use as highly efficient Pt-free counter electrodes of dye-sensitized solar cells," Solar Energy, vol. 107, pp. 660-667, 2014.

[9] I. Ahmad, J. E. McCarthy, M. Bari, and Y. K. Gun'ko, "Carbon nanomaterial based counter electrodes for dye sensitized solar cells," Solar Energy, vol. 102, pp. 152-161, 2014.

[10] L. Kavan, J. H. Yum, and M. Grätzel, "Optically transparent cathode for dye-sensitized solar cells based on graphene nanoplatelets," ACS Nano, vol. 5, no. 1, pp. 165-172, 2011.

[11] W. Maiaugree, M. Towannang, A. Thiangkaew et al., "Composited $\mathrm{NiSO}_{4}$ and PEDOT:PSS counter electrode for efficient dye-sensitized solar cell based on organic $\mathrm{T}_{2} / \mathrm{T}^{-}$electrolyte," Materials Letters, vol. 111, pp. 197-200, 2013.

[12] S. Yang, X. Li, W. Zhu, J. Wang, and C. Descorme, "Catalytic activity, stability and structure of multi-walled carbon nanotubes in the wet air oxidation of phenol," Carbon, vol. 46, no. 3, pp. 445-452, 2008.

[13] C. Lu, F. Su, and S. Hu, "Surface modification of carbon nanotubes for enhancing BTEX adsorption from aqueous solutions," Applied Surface Science, vol. 254, no. 21, pp. 70357041, 2008.

[14] S. Yang, W. Zhu, X. Li, J. Wang, and Y. Zhou, "Multi-walled carbon nanotubes (MWNTs) as an efficient catalyst for catalytic wet air oxidation of phenol," Catalysis Communications, vol. 8, no. 12, pp. 2059-2063, 2007.

[15] H.-C. Kuan, C.-C. M. Ma, W.-P. Chang, S.-M. Yuen, H.-H. $\mathrm{Wu}$, and T.-M. Lee, "Synthesis, thermal, mechanical and rheological properties of multiwall carbon nanotube/waterborne polyurethane nanocomposite," Composites Science and Technology, vol. 65, no. 11-12, pp. 1703-1710, 2005.

[16] W. Chen, X. Tao, P. Xue, and X. Cheng, "Enhanced mechanical properties and morphological characterizations of poly(vinyl alcohol)-carbon nanotube composite films," Applied Surface Science, vol. 252, no. 5, pp. 1404-1409, 2005.
[17] C. Dhand, S. K. Arya, S. P. Singh, B. P. Singh, M. Datta, and B. D. Malhotra, "Preparation of polyaniline/multiwalled carbon nanotube composite by novel electrophoretic route," Carbon, vol. 46, no. 13, pp. 1727-1735, 2008.

[18] A. R. Boccaccini, J. Cho, J. A. Roether, B. J. C. Thomas, E. Jane Minay, and M. S. P. Shaffer, "Electrophoretic deposition of carbon nanotubes," Carbon, vol. 44, no. 15, pp. 3149-3160, 2006.

[19] A. Gohel, K. C. Chin, K. Y. Lim et al., "Selective area growth of aligned carbon nanotubes by ion beam surface modification," Chemical Physics Letters, vol. 371, no. 1-2, pp. 131-135, 2003.

[20] B. Dong, B.-L. He, C.-L. Xu, and H.-L. Li, "Preparation and electrochemical characterization of polyaniline/multi-walled carbon nanotubes composites for supercapacitor," Materials Science and Engineering B, vol. 143, no. 1-3, pp. 7-13, 2007.

[21] L. Grinis, S. Dor, A. Ofir, and A. Zaban, "Electrophoretic deposition and compression of titania nanoparticle films for dye-sensitized solar cells," Journal of Photochemistry and Photobiology A: Chemistry, vol. 198, no. 1, pp. 52-59, 2008.

[22] K. Fredin, J. Nissfolk, and A. Hagfeldt, "Brownian dynamics simulations of electrons and ions in mesoporous films," Solar Energy Materials and Solar Cells, vol. 86, no. 2, pp. 283-297, 2005.

[23] S. J. Oh, Y. Cheng, J. Zhang, H. Shimoda, and O. Zhou, "Roomtemperature fabrication of high-resolution carbon nanotube field-emission cathodes by self-assembly," Applied Physics Letters, vol. 82, no. 15, pp. 2521-2523, 2003.

[24] H. Shimoda, S. J. Oh, H. Z. Geng et al., "Self-assembly of carbon nanotubes," Advanced Materials, vol. 14, no. 12, pp. 899-901, 2002.

[25] A. Sedghi and H. N. Miankushki, "Effect of multi walled carbon nanotubes as counter electrode on dye sensitized solar cells," International Journal of Electrochemical Science, vol. 9, no. 4, pp. 2029-2037, 2014.

[26] P. Luo, H. Niu, G. Zheng, X. Bai, M. Zhang, and W. Wang, "Enhancement of photoelectric conversion by highvoltage electric field assisted crystallization of a novel ternaryencapsulated spherical $\mathrm{TiO}_{2}$ aggregate for solar cells," Electrochimica Acta, vol. 55, no. 8, pp. 2697-2705, 2010.

[27] T. Yamaguchi, N. Tobe, D. Matsumoto, T. Nagai, and H. Arakawa, "Highly efficient plastic-substrate dye-sensitized solar cells with validated conversion efficiency of 7.6\%," Solar Energy Materials and Solar Cells, vol. 94, no. 5, pp. 812-816, 2010. 

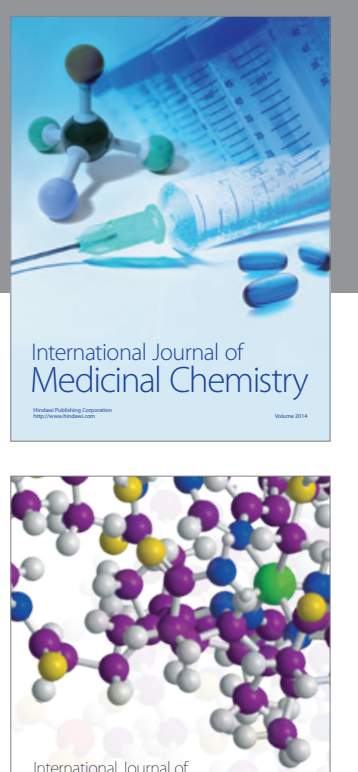

Carbohydrate Chemistry

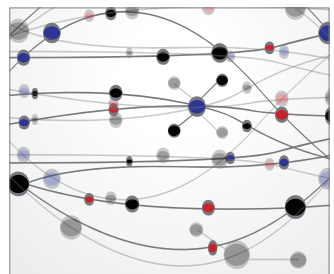

The Scientific World Journal
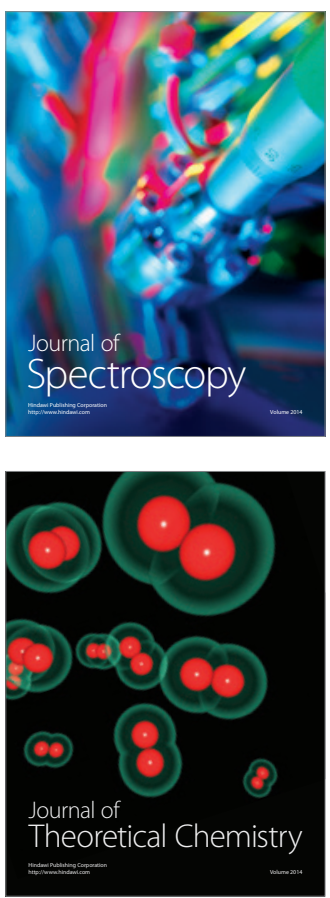
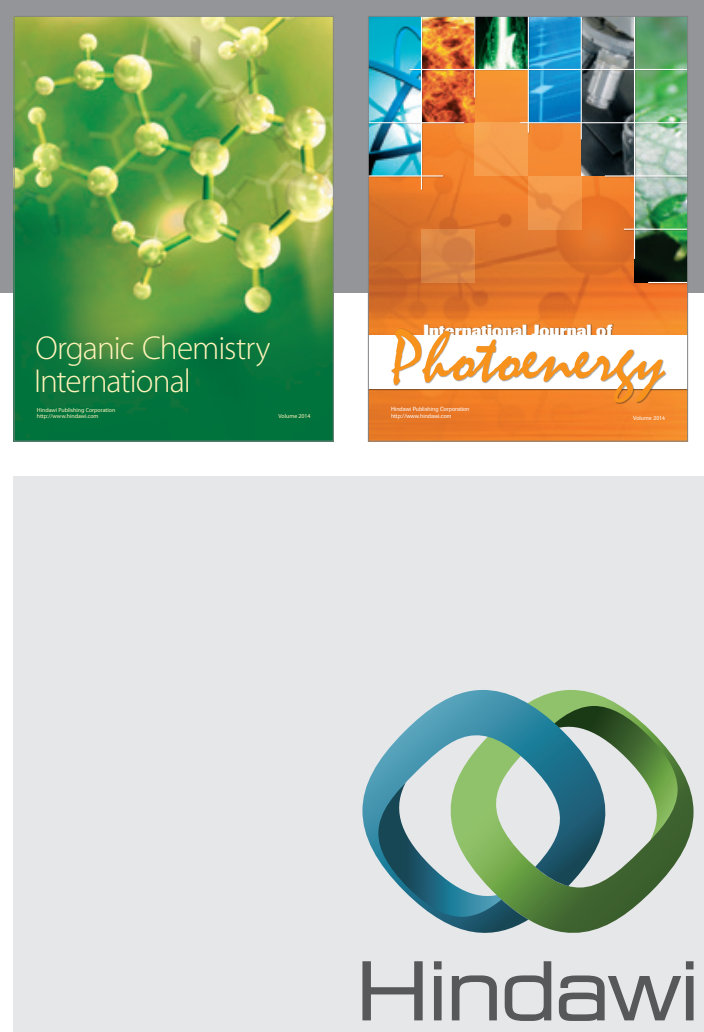

Submit your manuscripts at

http://www.hindawi.com

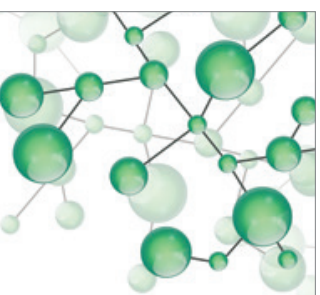

International Journal of

Inorganic Chemistry

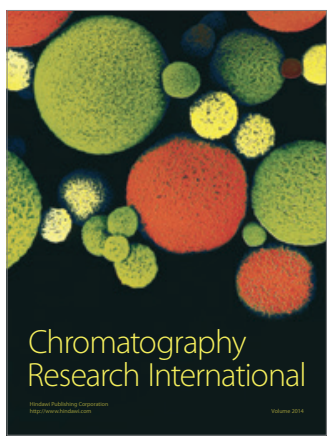

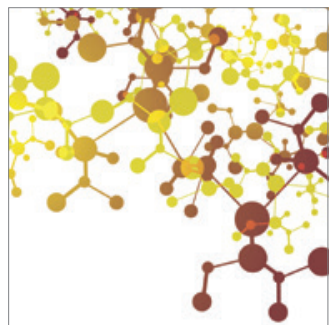

Applied Chemistry
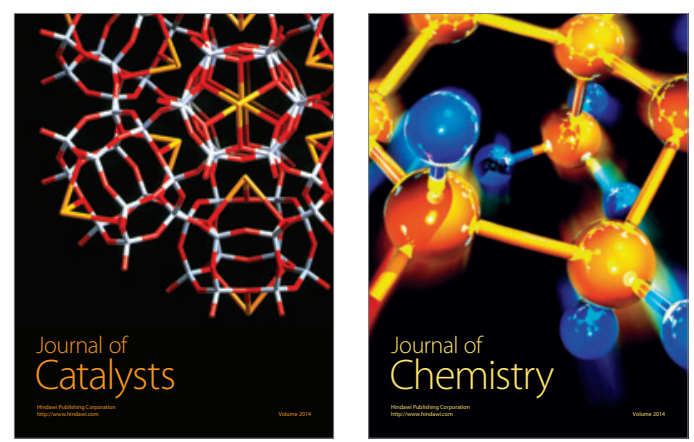
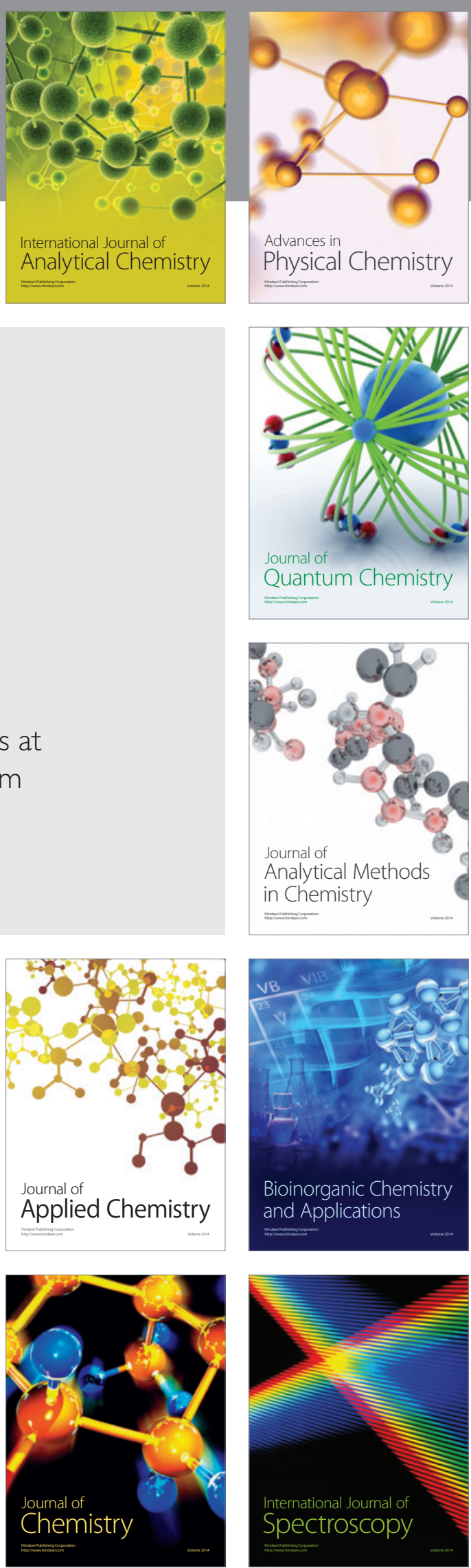